\title{
Role of a large plasmid of Salmonella typhi encoding multiple drug resistance
}

\author{
SHYAMALI KARMAKER, D. BISWAS, N. M. SHAIKH, S. K. CHATTERJEE," V. K. KATARIA* and \\ R. KUMARt
}

National Institute of Cholera and Enteric Diseases, P-33, C.I.T. Road, Calcutta-700 010, and "Command Pathology Laboratory (E.C.), Alipore, Calcutta, India

\begin{abstract}
Summary. Twenty isolates of Salmonella typhi from cases of typhoid during the 1989-1990 epidemic in Calcutta were examined. Most isolates $(84 \%$ of all isolates in the epidemic) were resistant to chloramphenicol, ampicillin, tetracycline and streptomycin but were sensitive to nalidixic acid and ciprofloxacin. Plasmids of $120 \mathrm{~kb}$ and $14 \mathrm{~kb}$ were identified amongst the multi-drug resistant isolates of $S$. typhi. However, there was no plasmid in the antibioticsensitive isolates. The $120-\mathrm{kb}$ plasmid was transferable and transconjugants were resistant to chloramphenicol, ampicillin, tetracycline and streptomycin. Restriction endonuclease analysis patterns after $E c o R I$ digestion of the $120-\mathrm{kb}$ antibiotic-resistance plasmids from the $S$. typhi isolates and transconjugants were similar.
\end{abstract}

\section{Introduction}

Typhoid is one of the most widespread of all bacterial diseases in eastern India. We have isolated Salmonella typhi from patients with typical symptoms of typhoid fever ${ }^{1}$ in a typhoid epidemic in Calcutta; 201 isolates were obtained from patients aged 2-60 years, most of whom presented with sudden onset of remittent fever and (about $2.5 \%$ came to hospital with jaundice and lower gastrointestinal bleeding). S. typhi was isolated from blood cultures in 175 cases; 26 patients were treated on clinical suspicion alone. All the strains were of phage type 51. Previous reports have indicated that treatment with chloramphenicol reduced the mortality rate of typhoid. ${ }^{2}$ However, early treatment seemed to increase the incidence of relapses. ${ }^{2,3}$ It has been reported that permanent recovery without relapse depends on the development of effective host immunity. ${ }^{4,5}$ Several workers have suggested that genetic factors are also important in susceptibility to typhoid in man. ${ }^{6-8}$ In most of the cases reported from Calcutta during 1989-1990, there was no response to treatment with chloramphenicol. The aim of the present study was to identify the genetic determinants of chloramphenicol resistance in S. typhi.

\section{Materials and methods}

\section{Bacterial strains and media}

$S$. typhi isolates from 20 patients with typhoid were

Received 15 March 1990; revised version accepted 3 Aug. 1990. † Correspondence should be sent to: Dr R. Kumar. obtained from Dr S. K. Chatterjee and Dr V.K. Kataria of Command Pathology Laboratory (E.C.) Alipore, Calcutta and several strains were isolated from patients from the Salt Lake and Calcutta areas. All the isolates were identified as $S$. typhi by biochemical and serological tests. Plasmids of Escherichia coli K12 strain V517 were used as standards for determination of the sizes of plasmids extracted from S. typhi. ${ }^{9}$ E. coli strain KL318 (F ${ }^{-}$, Pro-48, trp A9605, his-85, met $\mathrm{E} 70$, tro $\mathrm{R} 55$, lac I 22, azi 9, nal $\mathrm{A} 19$, rps $\mathrm{L} 171$, $\lambda^{-}$) was kindly supplied by Dr S. Palchoudhury, Wayne State University. The strains were grown in Tryptic Soy Broth (TSB; Difco) and on Tryptic Soy Agar (TSA; Difco).

\section{Antimicrobial susceptibility testing}

Antibiotic susceptibility tests were performed by the disk-diffusion method. Overnight (18-h) cultures in TSB were diluted 1:500 in fresh TSB and spread on TSA plates. The antibiotics were used at the following disk concentrations; chloramphenicol $(\mathrm{Cm}), 30 \mu \mathrm{g}$; ampicillin (Ap), $30 \mu \mathrm{g}$; tetracycline (Tc), $30 \mu \mathrm{g}$; streptomycin (Sm), $30 \mu \mathrm{g}$; nalidixic acid (Nal), $30 \mu \mathrm{g}$; ciprofloxacin (Cif), $2 \mu \mathrm{g}$.

\section{Conjugation conditions}

Donor (S. typhi) and recipient (E. coli KL318) strains were grown separately to exponential phase$(1-2) \times 10^{8} \mathrm{cfu} / \mathrm{ml}$. In all conjugation experiments, $0.1 \mathrm{ml}$ of a solution of DNAase I (Sigma) $1 \mathrm{mg} / \mathrm{ml}$ was added to both the donor and recipient cultures $10 \mathrm{~min}$ before mixing. Samples $(0.1 \mathrm{ml})$ of the donor cultures were gently mixed with $0.9 \mathrm{ml}$ of recipient $E$. coli 
KL318 culture and the mixture was incubated statically for $2 \mathrm{~h}$ at $37^{\circ} \mathrm{C}$. At the start of the conjugation period, samples of diluted donor and recipient cultures were plated separately on TSA plates with and without antibiotics. At the end of the incubation period the conjugation mixture was washed, diluted and spread on TSA plates containing $\mathrm{Cm} 30 \mathrm{mg} / \mathrm{L}$ and $\mathrm{Nal}$ $30 \mathrm{mg} / \mathrm{L}$.

\section{Isolation of plasmid DNA and restriction endonuclease analysis}

S. typhi strains, E. coli KL318, transconjugants and E. coli V517 were grown in $5 \mathrm{ml}$ of TSB medium with constant shaking for $18 \mathrm{~h}$ at $37^{\circ} \mathrm{C}$. The cells were harvested by centrifugation at $5000 \mathrm{rpm}$ for $10 \mathrm{~min}$ and washed with TE buffer ( $\mathrm{pH}$ 7.9). The plasmids were isolated by the procedure of Kado and Liu. ${ }^{10}$ Plasmid DNA of epidemic strains, donor and transconjugant were purified and then digested with $E c o$ RI (BRL) as described by Maniatis et al. ${ }^{11} \lambda$ DNA Hind III digest (Sigma) was used as a control for size determination. After electrophoresis, gels were stained with ethidium bromide and photographed. ${ }^{11}$

\section{Results}

\section{Antimicrobial activity and plasmid profiles}

Of $S$. typhi strains isolated from typhoid cases in Calcutta 1989-1990, 84\% were resistant to Cm, Ap, $\mathrm{Tc}, \mathrm{Sm}$ but sensitive to Nal and Cif. However, $16 \%$ of strains were sensitive to all these antibiotics. The plasmid profiles of representative strains were examined by agarose gel electrophoresis. All the $\mathrm{Cm}^{\mathrm{r}}$ strains contained only two plasmids, of $120 \mathrm{~kb}$ and $14 \mathrm{~kb}$. There was no plasmid in any of the sensitive strains of $S$. typhi. Plasmid profiles of representative isolates of S. typhi are shown in fig. 1.

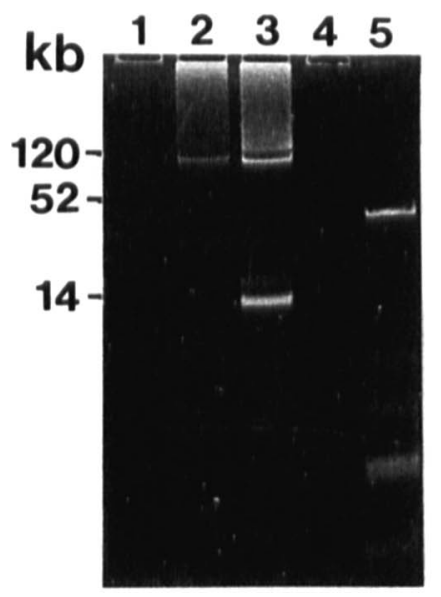

Fig. 1. Agarose gel electrophoresis of plasmid DNA from: lane 1, plasmid-less recipient $E$. coli $\mathrm{KL} 318 ; 2$, transconjugant; 3, donor $S$. typhi; 4, $\mathrm{Cm}^{\text {s }}$ plasmid-less $S$. typhi; 5, E. coli $\mathrm{K} 12$ V517 showing $52-\mathrm{kb}$ plasmid band as marker.

\section{Conjugal transfer of $\mathrm{Cm}^{r}$ plasmid and restriction endonuclease analysis}

Conjugation in mixed broth cultures is an efficient means of transferring plasmids to a new host for identification. $\mathrm{Cm}^{\mathrm{r}}$ donor $S$. typhi and plasmid-less recipient $E$. coli $\mathrm{KL} 318$ were mixed in a ratio of $1: 9$ for the conjugation experiment. The frequencies of transfer of $\mathrm{Cm}$ resistance determinants were calculated as numbers of transconjugants per donor; they were found to average $3 \times 10^{-5}$. The antibiotic-resistance patterns of 100 transconjugants were examined; all were resistant to $\mathrm{Cm}, \mathrm{Ap}, \mathrm{Tc}$ and $\mathrm{Sm}$. Plasmid profiles from more than 25 transconjugants were examined after agarose gel electrophoresis and each showed only one 120-kb plasmid DNA band corresponding with the donor $S$. typhi bands. Plasmid DNA profiles from donor, recipient and one representative of the transconjugant strain are shown on a representative agarose gel (fig. 1). The transconjugants had a tendency to lose plasmids. However, in $20 \%$ of $\mathrm{Cm}^{\mathrm{r}}$ transconjugants containing the $120-\mathrm{kb}$ plasmid the character was stable. Restriction endonuclease digestion with EcoRI of the $120-\mathrm{kb} \mathrm{Cm}^{\mathrm{r}}$ plasmids of the epidemic strains of $S$. typhi (donor) and transconjugants demonstrated that they were identical (fig. 2).

\section{Discussion}

Two distinct groups of $S$. typhi were isolated from cases of typhoid in Calcutta (1989-1990) -one antibiotic sensitive and the other multi-resistant. Plasmidless strains were sensitive to $\mathrm{Cm}, \mathrm{Ap}, \mathrm{Tc}$ and $\mathrm{Sm}$ whereas resistant isolates contained two plasmids $(120 \mathrm{~kb}$ and $14 \mathrm{~kb})$. Conjugation experiments demonstrated the transfer of a $120-\mathrm{kb}$ plasmid from $S$. typhi to $E$. coli and we may conclude that the $120-\mathrm{kb}$ plasmid encoded $\mathrm{Cm}, \mathrm{Ap}$ and $\mathrm{Tc}$ resistance determinants. $E$. coli $\mathrm{KL} 318$ has a resistance determinant to $S \mathrm{~m}$ resulting from the presence of locus rpsL171. Therefore the $\mathrm{Sm}^{\mathrm{r}}$

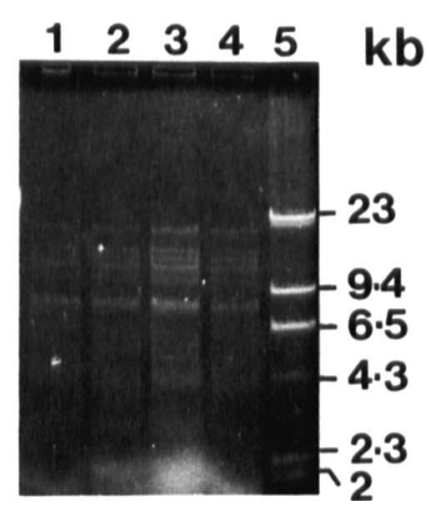

Fig. 2. $E c o$ RI restriction endonuclease analysis of $120-\mathrm{kb}$ plasmid DNA from: lane 1, a representative isolate of $S$. typhi from the epidemic; 2, donor $S$. typhi; 3 and 4, transconjugants; 5, $\lambda$ DNA digested with $H$ ind III. 
character of the transconjugants cannot be distinguished as plasmid mediated as it may derive entirely from the rpsL171 locus of the recipient. The $\mathrm{Cm}^{\mathrm{r}}$ strains of $S$. typhi must have evolved as a result of the indiscriminate use of chloramphenicol. Previously it was also observed that the $\mathrm{Ap}^{\mathrm{r}}$ character was acquired by Shigella dysenteriae type 1 when ampicillin was used randomly during the West Bengal (India) epidemic of $1984 .^{12}$ All the $S$. typhi strains isolated during the recent epidemic in Calcutta were phage

\section{References}

1. Anand AC, Kataria VK, Singh W, Chatterjee SK. Epidemic multiresistant enteric fever in eastern India. Lancet 1990; 1: 352 .

2. Marmion DE. The treatment of typhoid fever with chloramphenicol; a clinical study of 330 cases of enteric fever treated in Egypt. Trans $R$ Soc Trop Med Hyg 1952; 46: 619-638.

3. Cook AT, Marmion DE. Chloromycetin in treatment of typhoid fever. Lancet 1949; 2: 975-979.

4. Woodward TE, Smadel JE, Ley HL. Chloramphenicol and other antibiotics in the treatment of typhoid fever and typhoid carriers. J Clin Invest 1950; 29 : 87-99.

5. Knight V, Sánchez FR, Sánchez AR, Shultz S, McDermott W. Antimicrobial therapy in typhoid. Arch Intern Med 1950; 85: 44-82.

6. Naylor GRE. Incubation period and other features of foodborne and water-borne outbreaks of typhoid fever in relation to pathogenesis and genetics of resistance. Lancet $1983 ; 1$ : 864-866. type 51. ${ }^{1}$ The restriction endonuclease digestion patterns of the $\mathrm{Cm}^{\mathrm{r}}$ plasmid $(120 \mathrm{~kb})$ of the epidemic strains were all identical. Therefore, it appears that the large antibiotic-resistance plasmid $\left(\mathrm{Cm}^{\mathrm{r}}, \mathrm{Ap}^{\mathrm{r}}, \mathrm{Tc}^{\mathrm{r}}\right)$ of $S$. typhi is a common character of the recent epidemic strains of Calcutta.

We thank Dr S. P. De for helpful discussion and critical reading of the manuscript and $\mathrm{Mr}$ S. K. Das for secretarial assistance.

7. DeVries RRP, Meerakhan P, Bernini LF, Van Loghem E, Van Rood JJ. Genetic control of survival in epidemics. $J$ Immunogenet 1979; 6: 271-287.

8. Maskel DJ, Hormaeche CE. Relapse following cessation of antibiotic therapy for mouse typhoid in resistant and susceptible mice infected with salmonellae of differing virulence. $J$ Infect Dis 1985 ; 152 : 1044-1049.

9. Macrina FL, Kopecko DJ, Jones KR, Ayers DJ, McCowen SM. A multiple plasmid-containing Escherichia coli strain; convenient source of size reference plasmid molecules. Plasmid 1978; 1 : 417-420.

10. Kado CI, Liu ST. Rapid procedure for detection and isolation of large and small plasmids. J Bacteriol 1981 ; 145: 13651373.

11. Maniatis TE, Fritsch EF, Sambrook J. Molecular cloning: a laboratory manual. Cold Spring Harbor, NY, Cold Spring Harbor Laboratory. 1982.

12. Palchaudhuri S, Kumar R, Sen D et al. Molecular epidemiology of plasmid patterns in Shigella dysenteriae type 1 obtained from an outbreak in West Bengal (India). FEMS Microbiol Lett 1985; 30 : 187-191. 
